\title{
Tomasz Homa
}

http://orcid.org/0000-0002-4430-2591

Jesuit University Ignatianum in Krakow

tomasz.homa@ignatianum.edu.pl

DOI: $10.35765 /$ pk.2020.2801.08

\section{Joy and Sadness in Spiritual Life According to St. Ignatius of Loyola: A Hermeneutic Study Part II: Inspired by St. Ignatius of Loyola: Reading Feelings- An Attempt at Interpretation}

\section{AB S TRACT}

The purpose of this paper is to attempt to interpret human emotionality as expressed in the experiences of joy and sadness, in view of the precepts of one of the schools of Christian spirituality: Ignatius Loyola's teachings (14911556). According to this current of spiritual philosophy, which draws on the centuries-old experience of the biblical and Christian understanding of the emotional dimension of our lives, as well as the experiences and thoughts of Ignatius himself, our emotionality — often experienced as a kind of incomprehensible "buzz"-may, in reality, constitute equally emotional, legible "speech." This "speech" becomes understandable when we can properly "read," that is, recognize and understand, the emotional experiences we experience in this sphere. The article's reading feeling is a proposal of commonsensical-sapiential deciphering of both our emotional and emotional-spiritual experiences and joys and sorrows, as well as analyzing and interpreting them in the search for relevant meanings that they often carry or express.

KEYWORDS : character, emotionality, reading feelings, spiritual discernment, natural background: psychophysical, existentially situational, existentially constitutive, supernatural background, joy, sadness, emotional and emotional-spiritual states, temperament, feelings, spiritual life

Suggested citation: Homa, T. (2020). Joy and Sadness in Spiritual Life According to St. Ignatius of Loyola: A Hermeneutic Study. Part II. Inspired by St. Ignatius of Loyola: Reading FeelingsAn Attempt at Interpretation. Perspektywy Kultury, 28 (1), pp. 69-100. 


\section{STRESZCZENIE}

Radość i smutek w życiu duchowym według św. Ignacego Loyoli. Studium hermeneutyczne. Część II: Inspirując się św. Ignacym Loyolą: lektura uczuć - próba interpretacji

Celem tego studium jest próba interpretacji ludzkiej emocjonalności w jej uczuciowej formie wyrazu w postaci przeżyć radości i smutku, w świetle założeń jednej ze szkół duchowości chrześcijańskiej, mianowicie tej zaproponowanej przez Ignacego Loyolę (1491-1556). Według tego nurtu życia duchowego, czerpiącego zarówno $\mathrm{z}$ wielowiekowego doświadczenia biblijnego i chrześcijańskiego rozumienia emocjonalno-uczuciowego wymiaru naszego życia, jak i wniesionych do niego doświadczeń i przemyśleń poczynionych przez samego Ignacego, nasza emocjonalność doświadczana niejednokrotnie jako swoisty i często niezrozumiały „gwar” może, w rzeczywistości, stanowić równie emocjonalną, czytelną „mowę”. „Mowę”, która staje się zrozumiała z chwilą, gdy potrafimy właściwie „rozczytać”, czyli rozpoznać i zrozumieć, doświadczane przez nas w tej sferze emocjonalno-uczuciowe przeżycia.

Lektura uczuć, o której mowa w tytule tej części, to pewna propozycja zdroworozsądkowo mądrościowego rozczytywania naszych zarówno emocjonalnych, jak i emocjonalno-duchowych przeżyć i stanów szeroko rozumianych radości i/lub smutków oraz ich analizowania i interpretowania w poszukiwaniu nierzadko zawartych w nich istotnych dla nas znaczeń, których swego rodzaju nośnikami, czy też formami wyrazu, są niejednokrotnie właśnie tego rodzaju doświadczenia.

SŁOWA KLUCZE: charakter, emocjonalność, lektura uczuć, rozeznanie duchowe, podłoże naturalne: psychofizyczne, egzystencjalnie sytuacyjne, egzystencjalnie konstytutywne, podłoże nadnaturalne, radość, smutek, stany emocjonalne i emocjonalno-duchowe, temperament, uczucia, życie duchowe

\section{A few words about the method}

Reading feelings is a proposal for a commonsensical-sapiential reading of our emotional experiences and states as well as an analysis and interpretation of them in the search for the relevant meanings that they often carry or express.

My approach is situated in the philosophical current of a personalistic understanding of humanity, and is inspired by Ignatius of Loyola's experiences and thoughts on spiritual life, which were described in Part I of this essay, so it also makes an allowance for other dimensions of our life, which seem not to have been of direct interest to Ignatius. 
As an approach, it is only one possible way to understand and interpret our emotionality. It is a way that I would call hermeneutic, or rather hermeneutic-practical, given the fact that it focuses on both the problem of a hermeneutic nature-i.e., the problem of understanding either what we communicate or what is communicated to us by means of emotional forms of expression ${ }^{1}$ — and also a practical problem, namely, one concerned with providing "an adequate answer," that is, one that accounts for both the message contained in the experience and its source, i.e., the background and cause of this message, communicated to us in the language of emotions, as well as the good of our personal existence and/or development.

Indeed, this hermeneutic-practical reading of feelings is not (neither only nor primarily) a cognitive theoretical approach to our emotionality, consisting of an existentially-distanced search for a commonsensicalsapiential reading of our emotional experiences, focusing on the various sources/backgrounds that can cause them, their potentially diverse types, and the multiple forms of emotional expression that they can take. This approach $i s$ the search for an equally existentially-distanced, commonsensical, proper interpretation of any meanings that may be communicated to us through this type of experience. Without questioning the importance or necessity of such scientific theories, this reading is an attempt to transcend this scholarly distance of a purely theoretical approach to the emotionality that we experience existentially, by examining it both cognitively-theoretically and existentially-practically.

Many will likely agree that, taking into account the human daily experience of emotions, it seems that it can be reasonably assumed that if not all of them, then at least some can be conceived of as a kind of "language," which — as has already been mentioned - either we use to communicate with each other on the level of emotionality, or "the Other" (however understood) addresses us in such a language with a message to convey.

Similarly, many will probably admit that we are often unable to appreciate this hermeneutically linguistic function of emotional experiences and states, and its importance in our personal lives, as we experience these messages, generally, as a kind of incomprehensible and/or irrational "emotional static," or rather, as "white noise."

The possible recognition, in emotionality experienced thusly, of certain experiences and states that may function as a kind of language communicating to us, in its own particular way, something that would be

1 I borrow the understanding of the hermeneutic problem in the sense used herein in its essence from Paweł Dybel. According to him, "a hermeneutical problem [is] the problem of understanding what the Other is saying to me” (Dybel, P. [2012]. Oblicza hermeneutyki. Krakow: TAiWPN Uniwersitas, p. 17). 
existentially significant for us, requires — as in the case of any linguistic event-specific prerequisites.

In the case of reading feelings, such prerequisites will inevitably include self-knowledge, that is:

1. knowledge of our own psychophysical structure-especially our temperament - and its current condition,

2. events that build the "here and now" of our personal and interpersonal "everyday life/history," and our character,

3. our own idea for life, our own plan for life, i.e., the existential foundation and horizon of the meaning of our everyday life/history, and

4. personal life in faith.

\section{A variety of emotional and emotional-spiritual sources}

\section{of experiences and states}

The emotions that appear in us, as Ignatius pointed out in his autobiographical A Pilgrim's Journey, may have various sources or grounds, namely both natural and supernatural. The former-i.e., the natural sourcesencompass at least two feelings that are significant from the point of view of the reading of feelings and that will become the subject of the following terminological distinctions and analyses. These are psychophysical and existential sources. Among the latter category, the especially important ones are those that I would call existentially situational and existentially constitutive. As for the second type of sources of experiences and states that are of interest to us-i.e., supernatural sources-Ignatius, recalling his convalescence in A Pilgrim's Journey, generally mentions two of them, namely, one constituted by the actions of the good spirit-God and his angels - and the other by the actions of the evil spirit.

We must note here that these and similar natural and supernatural sources of our emotional experiences and states can occur both separately and simultaneously. An example of the separate occurrence is times. Ignatius recommends three ways of making a sound and good choice: during the first time, second, and third time. There are situations in which, as in the "first" time, only one spirit—one supernatural medium—which governs us, or as in the "third" time, when our actions spring from a natural source, when "the soul is not acted on by various spirits, and uses its natural powers freely and tranquilly" (Loyola, 1522-1524/2017, p. 46).

One of the examples of the second form, i.e., the simultaneous occurrence of emotional and spiritual states caused by essentially opposite sources during one spiritual experience that has chief significance for 
communication (in the sense referred to in the reading of feelings), is the second time. Ignatius introduces the dictum "so I ought to choose whatever I do" (Loyola, 1522-1524/2017, p. 45) as the prelude for making a choice. However, during the second time, unlike during the first and the third times, "the experience of the discernment of various spirits" causes both consolation and desolation during the decision-making process. Another example can be found in the A Pilgrim's Journey, where Ignatius describes the presence and action of an evil spirit in a serpentine form during his thanksgiving prayer after spiritual enlightenment on the shores of the Cardoner River (Loyola, 1553-1555/2001, p. 79).

Finally, when it comes to the example of the natural and supernatural factors coinciding and the significant relationship between them as a complex cause of spiritual awakening, I tend to identify it in another of Ignatius's spiritual experiences, which Father Luis Gonsalves da Cámara mentions in the Preface to A Pilgrim's Journey:

While Master Polanco and I were eating with him, our Father said that Master Nadal and others of the Society had many times asked him to do something, and that he had never made up his mind about it, but that, having recollected himself in his room after having spoken with me, he had had such great devotion and such a great inclination to do it, and (speaking in such a way as to show that God had given him great clarity on his duty to do it) he had made his mind up completely. (Loyola, 1553-1555/2001, p. 1)

\section{The reading of feelings - a case study}

In my attempts to decipher emotional and emotional-spiritual experiences, as well as states of joy and sadness in various forms of expression, which I propose later in this study, bearing in mind the inspirational nature of the study expressed in the title of this section, I limit myself to delineating only some of the possible directions of analysis of the selected types of experiences and states which have, or appear to have, only one source.

\subsection{Psychophysical background}

Emotionality analyzed in this case is an emotionality that, in its most rudimentary dimension, is a psychophysical reaction to equally psychophysical experiences. The hypothalamus, which is the primary center of the entire instinctive and emotional system, seems to play a key role in this kind of dynamics. 
As a center of instinctive and emotional life, the hypothalamus is the locus of primary biological needs and basic emotions (fear, aggression, and anger). The physiological symptoms which accompany emotions depend on it, such as sweating, tachycardia, changes in blood pressure, increased urine output, etc. In psychoanalytical terms, the hypothalamus could correspond to the deeper part of the human psyche, known as the id and unconsciousness. (Fedeli, 2003, p. 76)

Considered to be a psychophysically defined area of human life, which is inherently biological and natural, emotionality is an important component of the temperament (Fedeli, 2003, p. 85). At the same time, however, it may be significantly linked to our current psychophysical state. Therefore, the ability to read it and interpret any message it contains, as well as to provide an adequate response to it, requires self-knowledge, especially in the first area-one's own psychophysical individuality and its condition-as well as one's temperament.

Indeed, when looking at our own emotionality, it is not uncommon for us to notice certain regularities between such experiences and states and our psychophysical condition. For example, it is not difficult to observe that some usually quite fast-changing emotional experiences and states, like dissatisfaction, discouragement, or sadness, on the one hand, and contentment, cheerfulness, bliss, and joy, on the other, to name just a few, appear or intensify, usually in specific psychophysical circumstances.

The negative feelings arise, as a rule, in moments when our psychophysical immunity is overstrained or lowered, which may be caused by severe fatigue, weakness, illness, or stress. The positive ones arise when we protect or strengthen our psychophysical immunity, for example, by making sure to maintain a healthy lifestyle, work practices, and proper rest, which regenerates us.

However, everyday experiences also make us realize that although our current psychophysical state of being, which is inherently subject to change, is not inconsequential for the occurrence of specific experiences or emotions, nor is our innate and rather fixed temperament. Indeed, the strengthening or suppressing effect of our temperament on emotional experiences and states dawns on us with almost unquestionable obviousness.

With all this in mind, how can we attempt to decipher and interpret our experiences and emotional states, and, in the case under consideration, those that have a psychophysical and/or temperamental background? The "map" suggested below offers one of the methods for this kind of analysis which contains several coordinates of the commonsensical-sapiential charting of our emotionality. Without aspiring to be an 
all-encompassing tool, it nevertheless allows, in my understanding of the issue, to set out important directions in the search for both an understanding of our emotionality experienced differently by individuals and for a constructive approach to the communication it contains. Here are the coordinates:

A. The "Question": When does the 1) contentment/joy or 2) sadness/ dejection appear?

1. For example, "when I get enough sleep"; "when I run because I like running"; "when I feel adrenaline”; “...”

2. For example, "when I'm very tired, stressed, etc.”; “...”

B. "What's it all about?": an attempt to read and interpret the possible message

1. Maybe: "I'm in touch with myself;" "I've recharged my batteries"; “...”

2. Maybe: "I've reached my limit or crossed it"; “...”

C. "What's next?": an adequate response to the source/background of the emotional state

1. Maybe: "I'll stick to it, because it's useful for me, I benefit from it"; “..."

2. Maybe: "I'm going to rest, regain my strength, and these emotions will disappear or decrease"; “...”

D. A specific lesson to be learned

1. Maybe: "your psychological wellbeing really also depends on you"; “..."

2. Maybe: "get to know your capabilities and don't strain yourself"; “...”

The general lesson to be learned, which might seem obvious, not to say trivial, but often forgotten or neglected to our detriment, may be that in a vitally important way we communicate not only with others, but also with ourselves, and that we do so by using this particular language of emotions, among other things. Using the metaphor of railway signals, one could say that such emotional experiences and states often play the role of such signals that protect our psychophysical safety and healthy functioning.

Incidentally, practical knowledge of this type of emotional experiences and states, as well as their strictly natural determinants-not only inner, psychophysical-temperamental ones, but also those external, environmental, both of which are significant, especially in building and modeling the emotional tuning of oneself-not is alien to Ignatius. On the contrary, he is not only familiar with it, but he also recommends it in Spiritual Exercises in order for a retreatant to induce a specific emotional state in the 
psychological sense, so that he can engage more fully in the internalization of the subject of his thoughts and contemplations. ${ }^{2}$

\subsection{Existentially situational background}

Emotions born out of reactions to the various events that make up our existentially relevant - personal and professional-everyday life seem to be the second-most "typical" and common form of the emotionality we experience. Bearing in mind our basically personal involvement in these events, as well as their existential significance to us, I call them situations. However, due to their functions as sources of such or other experiences and emotional states, I call them the existentially situational background.

Interpersonal relationships, work, and social engagement, to list only some of these existentially important areas of our personal activity, are the realities which dynamically construct the aforementioned situations from which our everyday life is woven, and which shape, together with the social environment, the existentially understood story of each of us. These areas, due to their importance to us, often generate particularly intensively experienced emotionality. In this game, like in this socially significant everyday life, we are alone.

For this reason, experiences and states with an existential background in a situational sense are usually characterized by relatively high "readability," which allows us to pinpoint their source or multiple sources relatively easy. As a rule, we generally remember, for example, the start of an interesting friendship, some harm done to us, the promotion we received recently, or a successful initiative to which we devoted a lot of energy and time, as well as the emotions that they evoked in us or still evoke when we think about or remember them. Therefore, in the case of analyzing emotional reactions of joy and/or sadness with an existential situational background, both the memory of events which make up the everyday life of our personal and interpersonal here and now, and our history, as well as

2 For example, Ignatius advises a retreatant who wants to feel repentance and suffering for his own sins, so that he may help himself arouse such spiritual states by "tuning himself" mentally, creating an appropriate external environment. To contemplate better, he finds it useful "to deprive [himself] of all light, closing the blinds and doors while [he is] in the room, if it be not to recite prayers, to read and eat" (Loyola, 1522-1524/2017, p. 31). Similarly, for those who desire to experience "joyful thoughts, although good and holy, as, for instance, are those on the Resurrection and on heavenly glory" (Loyola, 1522-1524/2017, p. 51), he recommends "to use light or temporal comforts - as, in summer, the coolness; and in winter, the sun or heat - as far as the soul thinks or conjectures that it can help it to be joyful in its Creator and Redeemer" (Loyola, 1522-1524/2017, p. 55). 
the awareness of one's own character, so the second of the areas of broadly defined self-knowledge plays a particularly important, although not exclusive, role.

We must note, however, that, unlike psychophysical and temperamental emotions, this type of emotionality does not have so much to do with our innate temperament, but rather mainly with our character, shaped by both ourselves and by the social environment in which we live. However, the influence of the first background, especially the temperamental one, usually has a significant impact on the way we experience existentially situational emotions, namely, above all, on their "color" and intensity. Nevertheless, the various "influences" of the psychophysical and temperamental background, regardless of how major its effect on the situations we experience is, should be clearly distinguished from the existentially situational background, which I consider to be the source of joy and/or sadness.

Indeed, despite the fact that both these backgrounds are essentially natural, they differ considerably. As for experiences and emotional states which are rooted in our psychophysical condition and temperament, we are dealing, fundamentally, with influences that are independent of our will, as they are innate "needs" and "behaviors." However, with emotions rooted in existential situations, our "values" come to light, as do our more or less conscious and free "actions": undertakings that make our decisions a reality, and which are somehow related to values.

Considering existentially situational emotional states and experiences, as previously, let us use a "map" to read and interpret them, bearing in mind its limitations and simplifications, as well as the illustrative nature of possible readings of them.

A. The "Question": When does the 1) contentment/joy or 2) sadness/ dejection appear?

1. For example, a) "when I meet with people close to me"; b) "when my work fulfills me and, at the same time, is noticed and appreciated in various ways"; c) "when I can help someone;" "when ..."

2. For example, a) "when things are not so good between us"; b) "when my professional development and advancement have stalled"; c) "when I experience different forms of heartlessness, anonymity, alienation, or indifference"; "when ..."

B. "What's it all about?": an attempt to read and interpret the possible message

1. Maybe: a) "the experience of closeness and acceptance from being with people with whom I have emotional bonds is vitally important to me: it opens me up, strengthens me/gets me back 
on my feet, brightens me up ..."; b) "recognition in the eyes of others is important to me: it motivates me, brings me a sense of security, boosts my confidence, enhances the mental comfort of my work ..."; c) "truly, 'It is more blessed to give than to receive"” (Acts 20:35)

2. Maybe: a) causally — "it hurts, divides, and/or destroys me/us ..."; communicatively_ _I/we can't find common ground ..."; prospectively — "the bonds which are fundamentally important to me are threatened and my/our world might fall apart ..."; existentially — "I miss it terribly/I'm 'hungry' for this deep warmth and light of our mutual openness, acceptance, and closeness ..."; b) "I'm suffocating ..."; I'm burnt out ..."; “where is the recognition and appreciation, I give my best - this treatment is unfair ...”; c) "I can't live like that! ..."; "why ...?"; "it's a nightmare! ..."; "but why be good to others?!"

C. "What's next?": an adequate response to the source/background of the emotional state

1. Maybe: a) "I will prudently cherish and develop these valuable relationships of acquaintance, friendship, and love in their various aspects: the time I dedicate to them, the mindfulness, the gestures of closeness I show, the reciprocity, my participatory presence, the verbal and non-verbal communication ..."; b) "I will maintain my current style of professional commitment, applying the principle of yes for working 'with a human face' and no for dehumanizing perfectionism and the rat race ..."; c) "Keep up the good work. I will continue to act in this way, because the reason for my joy is the good of the person I help (treating a person in need like a subject, not an object) ..."; "only not like this" (if the real motivation of my helping others is mainly seeking my own complacency or self-affirmation, and thus, instrumental treatment of people in need) ..."

2. Maybe: "I will try to face these existentially situational difficulties and crises that I am experiencing, trying to transform them into qualitatively new stages of my a) interpersonal, b) professional, and c) social realities, knowing that - realisticallymore or less, but not everything is up to me." Thus, specifically and "adequately," maybe: in interpersonal relationships_- "I will search for understanding of, an explanation for, and a positive solution to the problem. Empathy or “getting inside another's skin," i.e., putting myself in their shoes and examining the bone of contention between us, from their point of view, can help me better understand their attitude, and at the same time teach 
me more about the actual source of the crisis we are experiencing, and thus to fully understand the meaning of the sadness that this crisis evokes in me. An honest conversation turning into a dialogue seems to be the most suitable way of fruitfully overcoming our crisis ..." or also "..."; in the professional realities of life- - "getting stuck in a dead-end job" is not what I expected to be the capstone of my professional career. I need to diagnose its causes, - those that I have influence over and those that I cannot influence-draw conclusions, and give myself a new chance, despite the despondency overcoming me: failures happen, errare humanum est" or also "..."; in the social realities of life-"heartlessness, anonymity, and indifference dehumanize me, poison me, and kill me. I do not agree to this. These toxins, unfortunately, are not only around me, but also inside me. What I can do is start from myself, trying, by choice, to be less toxic to myself and to others-less heartless, anonymous, and indifferent - and the sadness and dejection they arouse will start to dissipate, after all life is sweeter and brings more happiness, the less our poisons are in it ...”; or also “...”

D. A specific lesson to be learned

1. Maybe: "My multifaceted social world is built on the foundation of values which are existentially important to me, especially acceptance, closeness, love, openness, creativity, understanding, and recognition. When I manifest these values in social life, they also become vehicles and forms of expression. These values give my life depth, taste, splendor, and energy and are important sources of my existentially situational emotions of joy ..."

2. Maybe: "Emotional states of sadness with an existential background signal difficulties and crises in various spheres of my personal, subjectively concretized existence. Ultimately, they signal the threats of annihilation of my vital values that constitute the sense-generating structure of my life understood in this way."

E. A general lesson to be learned: Perhaps the fact that existentially situational emotionality brings to light the fact that apart from vital physical and psychological needs belonging to the sphere of our human corporeality, values oriented towards us as human beings and recognized in the psycho-spiritual dimension of our lives are no less important for us, as people, for our human existence as subjects. Their importance, which we experience every day, is that they enable us an extremely important-namely, existentially qualitative-fulfillment of the personal dimension of our life, that is, its "saturation" with both important concretizations of our humanity, 
lived fully thanks to the realization of these values and the "depths" and "joys" proper to these values, which are essentially as deep as the values of their source are higher (Scheler, 1967, p. 1521).

\subsection{Existentially constitutive background}

Emotionality accompanies all areas of our humanity; that's what experience teaches us, be it ours or other people's. The emotionality we experience in the context of making the most important existential decisions, or more broadly, in the sphere of what concerns the foundations of our existence and its fundamental shape, is the third extremely important form of emotional experiences and states.

Because their sources have key meanings for our lives, I call these emotions states with an existentially constitutive background. This is a background that belongs to the sphere of understanding of ourselves and the world around us, which is fundamentally important to us, and in the context of the actions we take in which-to quote Socrates's thought on human life- "For it is no ordinary matter that we are discussing, but the right conduct of life" (Plato, 375 BCE/2008, 352d). So, more precisely speaking, these are the sources that belong to our most important sphere, the existentially sense-producing thoughts and choices about "who and how we are" and "who and how we want to be," as well as the closely related search for answers to the often gnawing question about the principle which guides our whole life, or about its leading value that we could stick to what "would make living most worthwhile" (Plato, 375 BCE/2008, 344e). At the same time, these sources also belong to our sphere of existentially primary actions, derived from these musings, which concretize this kind of search for the guiding principle/value ${ }^{3}$ and which we raise to the rank of constitutively sense-producing and sense-carrying fundament the already conceived, or the already fulfilled plans of our personal life. That is why the experiences and emotional states generated by the sources which I define as existentially constitutive differ significantly from existentially situational

3 Speaking of the guiding principle-value, I am not ascribing value to it yet, i.e., I am not indicating that it is positive or negative, but only paying attention to its axiological nature, whose valence, depending on the value that founded it, should only be recognized or understood. I share Max Scheler's view that "we must point out the significant fact that all values (ethical, aesthetic, etc.) are divided into positive and negative values (speaking in simplistic terms). This is inherent in the essence of values and holds true (gilt) quite independently of the fact that we can sense (fühlen) these particular opposites of values (i.e., positive and negative values), like we sense the opposites of beautiful-ugly, good-bad, pleasant-unpleasant, etc.” (Scheler, 1967, pp. 1512-1513). 
emotionality, stirred up by various forms of our personal, existentially significant, activity in the sphere of interpersonal, professional, and social everyday life, i.e., being with others and for others, although, for obvious reasons, there can be, and usually are, substantial dependencies between these two types of emotional experiences.

If I tried to capture the essential differences between them, in my understanding, these are in the case of emotionality described herefirst of all, its background, that is, our personal, existentially constitutive being towards ourselves and for ourselves, whose essence, in general terms, involves coming "face to face" with one's own life and taking it into one's own hands to shape it the way one desires. This being, if treated personalistically, does not lose sight of being with others and for others; it rather constitutes a fundamentally important and necessary basis for such a socially realized dimension of our personally realized existence. Secondly, this difference is complementarily and indicatively aggravated by the fact that this kind of emotional experience and state is treated as a unique "language" in which we communicate something in an emotional way, referring us to the existentially deepest understanding of the bases, goals, and ways of fulfilling our human potential in this world, and thus, also to their ultimate foundations and horizons of meaning. Finally, thirdly, considering the way of experiencing these emotions, whose existentially constitutive sources have their ultimate foundations in the spiritual dimension of our human being, it differs from the ways of experiencing psychophysical and existentially situational emotionality, especially in the degree of some spiritual saturation proper to this radically primal, sense-producing all-encompassing depth and gravity.

Therefore, in order to read and interpret experiences and states with an existentially constitutive background, reaching for the already familiar "map" leading us, in this case, to the spiritual dimension of our humanity, co-determined in a significant way by our human openness to transcendence, freedom, rationality, decision-making power, judgement, and, consequently, personal responsibility, knowing your own life plan-its existential foundation, and its horizon of meaning, i.e., the third of the signaled areas of self-knowledge - appears to be indispensable here. Having made these clarifications, let us now proceed to the attempt to decipher such experiences and existentially constitutive states.

A. The "Question": When does the 1) contentment/joy or 2) sadness/ dejection appear?

1. For example, a) "when I discover/am able to tell myself/experience the certainty of what I want to do in life and how I want to live"; b) "when I manage to carry out the plan I have for my 
life"; c) "when I act/try to live up to my values and understanding of how I want to live despite all odds"; "when ..."

2. For example, a) "when I feel lost in life"; b) "when what is most precious in my life is underestimated, neglected, or destroyed"; c) "when I experience the grotesque quality of life, which mercilessly consumes and absorbs me more and more"; "when ..."

B. "What's it all about?": an attempt to read and interpret the possible message

1. Maybe: a) "I found my pearl"; "I have an idea for my life"; "I take my life into my own hands"-fascination, challenge, the taste and thrill of adventure, the certainty of the direction of life (orientation in life), awareness of its importance and values for me, catching the "wind in your sails"; “...”; b) "my life is mine”; "it worked ... it was worth it ... that's it!"; "keep at it!"- the experience that my life is really up to me, the joy of fulfillment, the enthusiasm of action, motivational recharge, satisfaction and pride, self-confidence, a sense of my own power to make things happen”; “...”; c) "that's what you should do"; "it makes sense"; "I can breathe!"; "I am myself and in my place"; "I can look myself in the mirror"-confirmation that my own choices were right, awareness of the proper foundation of life, satisfaction with sticking to my own compass, experiencing authenticity and loyalty to myself, self-respect, dignity, and pride”; “...”

2. Maybe: a) "where is the compass of my life?"; "what am I doing?"; "my idea for life is not working!"; "I'm wasting my life?!"; "I don't know what to do"; "Boor, you had the horn of gold"-confusion, stupefaction, helplessness, uncertainty, disorientation, frustration, blame, bitterness; “...”; b) "my life is threatened"; "I am insulted, destroyed, humiliated, and despised ..."-resistance, rebellion, insecurity, acceptance, support, awareness of harm, injustice, hopelessness; “...”; c) "life is absurd, pointless, inhumane, and ideas for its good management are a toxic illusion"; "Carpe diem!"; "How should one live?"; "I can't go on like that!"-frustration, disappointment, irony, cynicism, tragedy, comedy, illusoriness, suspicion, powerlessness, anger, despair"; “...”;

C. "What next?": an adequate response to the source/background of the emotional state

1. Maybe: a) "I will verify whether my idea of life is reasonable and good. To this end, I will first give calm consideration to the reasons underlying my belief in what I want to do in life and how I want to live, that is, their content - these are usually 
arguments 'in favor of' a given vision of life; their character, that is, are they of an emotional, rational, or religious nature ...; their respective backgrounds, namely, what lies behind them-my personal experiences, thoughts, and fascinations with someone or something ...; and the criteria of their truth and validity for me, that is, why I believe them and lean towards them. Next, I will analyze the criteria of my choice of what I want to do in life and how I want to live, i.e., what motivated me in making the decisions? For example, was it thirst for adrenaline, challenge, the taste and thrill of adventure, a vital necessity of the moment, recognition of my life path and its purpose ..."; or also "..."; b) "I will try to follow the principle of 'keep going!' given that although this expression might seem obvious and even trivial, this is not the case if I want to think about the 'how' and 'where to' of my seemingly trivial 'keep going!' After all, experience teaches that every choice, even a reasonable and good choice for the shape of our lives, requires constant mindfulness to put it into practice wisely, that is, to do so in such a way that cares about both the quality of the realization of the project we have chosen and the very shape of life that is proper to it, so that together they translate into our integral growth in humanity in all its dimensions. Hence, the question of 'how' in regards to this 'keep going!', i.e., the way and quality of our taking our life into our hands is vitally important to the success of this fundamental undertaking of our life. This question, referring to Jesus's wisdom, asks whether, among other things, figuratively speaking, we erect the edifice of our life on 'sand' or on 'rock' and whether, by taking this up, we will not only be able to erect some more or less impressive foundations, perhaps arousing our pride and satisfaction, but also whether we will bring this work to its successful completion, that is, to our fulfillment in humanity according to the possibilities which each of us possesses. The same applies to the question of 'where to' for this 'keep going!', because it also_considering the dynamism of our life and our deeper investigation of it - confronts us with a vital issue, namely, the further existentially essential concretizations of the plan for our lives, their recognition and prudent introduction to the plan.”; or also “...”; c) "I will conduct myself in accordance with my values and understanding of how I want to live, the first criterion for recognizing the rightness of my decisions. Additionally, I will make the accompanying states of spiritual contentment and/or joy arising under the influence of this 
kind of compatibility an important aspect of the criterion of spiritual confirmation of their rightness, and by the same token of them being good to me."; or also “...”;

2. Maybe: a) "I will attempt to constructively work through my experience of feeling lost in life, starting with the recognition of the nature of this 'getting lost' I am experiencing. It can signal getting lost in life in the sense of a partial or total loss of this life, namely, more or less the loss of its meaning, authenticity, validity, legitimacy, or power ..., as in a situation of living with a guilty conscience, contrary to one's beliefs and values ..., or also a total loss, as in the situation of existentially utterly 'selling yourself out' to someone or something. However, it can also mean not so much a loss in life, but rather losing one's way in life in at least two different interpretations: in the first interpretation, when I take on the position of an onlooker who is looking at my plan for my life, instead of proceeding to its fulfillment, taking the spectral, often illusory image of my own life to be its real, existentially life-giving concretization, 4 or in the second interpretation, when I not only live somewhere suspended between the world of my imagined life and the world of real life, but also when this world of my imagined life has nothing to do with the world of my real life, and does not stand up to the collision with its actual realities. The experience of getting lost in life does not necessarily mean 'losing one's way in life,' although it can express a kind of failure of one's own idea for this life. When I encounter this failure I can give up or treat it as a life chance for an existentially important correction of both my approach to my own life plan and the correction of the plan itself, if it existentially somehow 'fails,' that is, it contributes to my getting lost."; or also “...”; b) "This is an extremely important and difficult lesson of the truth and art of living "here and now' in this temporal human world: everything that is truly 'valuable' in our lives 'costs' something; therefore, if we do not want give up these 'valuables,' we have to be prepared to bear their costs. This fact, which many of us will strongly contest,

4 This situation, by analogy, seems to be aptly characterized by the exhortation of James the Apostle: "Do not merely listen to the word, and so deceive yourselves. Do what it says. Anyone who listens to the word but does not do what it says is like someone who looks at his face in a mirror and, after looking at himself, goes away and immediately forgets what he looks like. But whoever looks intently into the perfect law that gives freedom, and continues in it - not forgetting what they have heard, but doing it - they will be blessed in what they do" (James 1: $22-25)$. 
shows us inexorably the need to learn the 'skill of paying' such bills, which means paying them wisely, that is, in a way that contributes to our growth as human beings. The Wisdom of Sirach, in my opinion, offers special council on how to do it wisely, speaking of the 'costs' of what is 'precious' in life, while doing so in relation to this particular form of 'preciousness' which is serving God, nevertheless, without losing, therefore, its universal validity and the possibility of applying it to all other forms of the true 'preciousness' of human life. The book advises, "My child, if you come to serve the Lord, prepare yourself for testing. Set your heart straight, be steadfast, and don't act hastily in a time of distress. Hold fast to God and don't keep your distance from him, so that you may find strength at your end. Accept whatever happens to you, and be patient when you suffer humiliation, because gold is tested with fire, and acceptable people are tested in the furnace of humiliation. Trust him, and he will help you; make your ways straight, and hope in him" (Sirach 2: 1-6).

Undoubtedly, the wisdom of this advice is both very demanding and shocking, in at least a double sense. At the same time, however, it is also optimistic advice. It is demanding because it encourages its addressee to live a life radically entrusted to God, extreme to the point where the form of this life will be considered by many of us to be extremely impractical, because it expects us to rise to the heights of heroism buttressed only by the hope of unlimited trust in God. And all this, in the name of 'preciousness' that is supposed to be significant content in our lives, to impart its sense-carrying importance and vitality from nowhere other than this preciousness, which is the ultimate foundation and horizon of meaning for both this particular preciousness of the biblical addressee and his whole life, that is, from God himself. It is also shocking because, first of all, it reveals the special drama of human existence in the words 'prepare your soul for experiences,' from being tested in different ways, which is inscribed in our life here and now, to experiences expressed metaphorically in the concept of a 'furnace of adversity' in which, according to The Wisdom of Sirach, people who are pleasing to God are tried. I will return to this topic later in the study. On the other hand, secondly, this advice is also shocking in the sense that revealing this aspect of our human existence, which is so dramatic in its core, this shock shakes our expectations of our life and its imaginations. Finally, it is also optimistic advice, because it reveals the widest horizon of the 
realization of our existence and its ultimate fulfillment, set by God himself - the horizon of what is 'supernatural', the horizon that embraces all the horizons of what is 'natural' in which we have moved so far, maintaining their importance, and concurrently infinitely exceeding them with all-encompassing fullness. Therefore, perhaps, it is worth considering this advice in our possible search for ways to 'pay' wisely for 'valuables', which are a weighty content of our lives.”; or also “...”; c) "I'm going to analyze the grotesqueness of life that I'm experiencing, taking into account its forms of expression that I experience in my life and around me, as well as their nature, possible sources, and possible interrelationships. The grotesqueness that I experience is not something ineligible and irremovable, which suddenly falls on me like some Greek fate, but on the contrary, it is something whose presence and scale in my life are more or less dependent on my personal choices, and not on other ideas for my life and their concretizations."; or also "...";

D. A specific lesson to be learned: Maybe "experiences and states with an existentially constitutive background direct our attention to the deepest foundations of our humanity, both in its natural and supernatural dimensions, that is, to the spiritual foundations of our existence, its key values for us, and also to the conceptualization in reference to them, or to already fulfilled ideas for life (life plans). Considering the latter, they direct our attention especially to the criteria of their selection, the ways of concretizing and reformulating, strengthening, finding, and/or rebuilding. At the same time, these experiences show us both the indelible drama of our existence springing from our freedom-which constitutes us personally, as bodily-spiritual beings - and the possibility of realizing the grotesque form of its concretization which accompanies this existence, and somehow lies in our power (precisely due to such a creative embedding in the freedom given to us), casting a peculiar shadow over the existence of each of us."; or also “...”;

E. A general lesson to be learned: maybe the lesson about one of the paradoxes of our existence, which is fundamentally important in its existentially constitutive dimension, is that in us people, "there is a strange duality in the human which makes for an ethical paradox. We have definitions of good qualities and of bad; not changing things, but generally considered good and bad throughout the ages and throughout the species. Of the good, we think always of wisdom, tolerance, kindliness, generosity, humility; and the qualities of cruelty, greed, self-interest, graspingness, and rapacity are 
universally considered undesirable. And yet, in our structure of society, the so-called and considered good qualities are invariable concomitants of failure, while the bad ones are the cornerstones of success. A man — a viewing-point man-while he will love the abstract good qualities and detest the abstract bad, will nevertheless envy and admire the person who possessing the bad qualities has succeeded economically and socially, and will hold in contempt that person whose good qualities have caused failure. When such a viewing-point man thinks of Jesus or St. Augustine or Socrates, he regards them with love because they are the symbols of the good he admires, and he hates the symbols of the bad. But actually he would rather be successful than good" (Steinbeck, 1951).

The presence of this kind of dualism in us, generating an existentially significant tension between the ideals and values we admire, declare, and/or choose and the realities we sometimes desire-in the form of emotional experiences and states, as well — involves the need to constantly explore our own way of life, to internalize values constituting its foundation and horizon of meaning, and to learn the ability to justify one's life choices, especially to oneself ..."; or also "..."

\subsection{Supernatural background}

We are physical and spiritual beings who belong to the world of "what is natural" and give it a significant expression in emotional experiences and states of joy and sadness, among other things, which we experience many times, stirred up by sources of an equally natural character, which have been mentioned so far. Nevertheless, in our integrally and inalienably bodily-spiritual existence in the world of "the natural," we not only belong to it, but we also transgress beyond it, as we are essentially open to the wholeness of reality, both natural and supernatural, and at the same time in this openness, we are capable of entering specific interactions with it.

This fundamentally important fact of being open in our core finds its existential expression in our transgression towards everything transcendent to us, in both the sphere of "the natural" and of "the supernatural," towards the causative cause, the ultimate horizon of meaning and the ultimate goal, namely, towards Transcendence, which in the Judeo-Christian experience of faith makes God known to us as a personal God. On the other hand, however, he also finds his existential, fundamentally important expression in some encroachment into our bodily and spiritual being in this world, into all that is transcendent (in the sense we have already 
mentioned above), until the Transcendence Itself, or God, enters our lives. A special embodiment of this openness and accompanying emotionality, which is essentially specific to our human nature and which will become the subject of the following analysis, is the transgression towards "the supernatural" as well as the intrusion of "the supernatural" into our bodily and spiritual existence, i.e., transgression-intrusion, which I call religious experience in a broad sense.

The experiences and emotional states which are the fourth fundamentally important form of emotionality considered in this essay are situated within the kind of experience that significantly expands the horizon of our lives (analyzed so far in their physical, psychological, and spiritual dimensions) by the spiritual-religious dimension appropriate for them, co-determined by what is "natural" and what is "supernatural."

These experiences of spiritual-religious life-both biblical, which was expressed by the author of the First Letter of John the Apostle, who points to the basic criterion for knowing their true nature: "Beloved, believe not every spirit, but try the spirits whether they are of God" (1 John 4:1) and extra-biblical, the model example of which, concretized in the life of Ignatius Loyola was discussed in the first part of this essay, teach us that experiences and states appearing in us as well as joy and sadness related to spiritual and religious life can be aroused by both natural and supernatural sources, ${ }^{5}$ and among the latter, generally speaking, by the actions of a good spirit, and of a bad one.

Given the assumptions of this essay, namely, its limitation to the analysis of selected types of experiences and emotional states that have or appear to have only one source, the subject of my thoughts below is these forms of emotional expressions in the sphere of spiritual and religious life that have a supernatural background. Therefore, in the context of broadly defined religious experience, in order to properly read the nature of the emotional states experienced as part of it and to read and interpret the important messages contained within them, the above-mentioned multifaceted knowledge of ourselves becomes necessary, with particular emphasis on the knowledge of the personal life of faith, or its fourth dimension. This, in turn, when it comes to this work, means knowing both the universally important principles of a life of faith, in the Christian understanding, and our personal way of living it. And in the case of the former, i.e., the principles of a life of faith, this knowledge presupposes, at the very least, a basic knowledge of how the spirits of good and evil operate in our

5 For more on the possibility of experiences and emotional states coexisting with natural and supernatural sources see the section $A$ variety of emotional and emotional-spiritual sources of experiences and emotional states in this essay. 
human life and what the rules for recognizing these spirits are-and, as a consequence, how to distinguish between their actions-as well as our responses to such manifestations of the intrusion of the supernatural into our lives. In addition, it is more than recommended, it is desirable to have someone who already has solid experience in the sphere of spiritual and religious life in this regard accompany us in this kind of reading of spiritually emotional states and in the discernment of their supernatural sources.

Abiding by the inspiration of the spiritual experiences of Ignatius Loyola, it is worth recalling three of his rules for the "discernment of spirits", rules "for perceiving and knowing in some manner the different movements which are caused in the soul-the good, to receive them, and the bad to reject them" (Loyola, 1522-1524/2017, pp. 76-79). These rules, which were already mentioned in Part I of this essay, say that they will help us in reading and interpreting spiritual and emotional states which are aroused in us by various movements which are happening in the soul and coming once from the good spirit and once from the evil spirit, such as thoughts, ideas, desires, consolation, and distress.

Third Rule. The third: With cause, as well the good Angel as the bad can console the soul, for contrary ends: the good Angel for the profit of the soul, that it may grow and rise from good to better, and the evil Angel, for the contrary, and later on to draw it to his damnable intention and wickedness

Fourth Rule. The fourth: It is proper to the evil Angel, who forms himself under the appearance of an angel of light, to enter with the devout soul and go out with himself: that is to say, to bring good and holy thoughts, conformable to such just soul, and then little by little he aims at coming out drawing the soul to his covert deceits and perverse intentions.

Fifth Rule. The fifth: We ought to note well the course of the thoughts, and if the beginning, middle, and end is all good, inclined to all good, it is a sign of the good Angel; but if in the course of the thoughts which he brings it ends in something bad, of a distracting tendency, or less good than what the soul had previously proposed to do, or if it weakens it or disquiets or disturbs the soul, taking away its peace, tranquility, and quiet, which it had before, it is a clear sign that it proceeds from the evil spirit, enemy of our profit and eternal salvation. (Loyola, 1522-1524/2017, p. 79)

Bearing in mind the above reflections and rules, let us now move on to an attempt to read the typologically outlined different types of possible experiences and states with a supernatural background. 
A. The "Question": When does the 1) deep satisfaction, inner spiritual joy, and happiness or 2) spiritual sadness, dejection, despair, and anxiety appear?

1. For example, a) "when I feel that I am acting in accordance with faith and God's will being discovered in it"; "When I try to live in such a way that my life is a testimony of faith and love for God and for people"; b) "when I 'feel' God's presence in my life and want to live in this presence"; c) "when I 'modernize' God's commandments and my life of faith in the spirit of ideology and cultural trends, in a variety of ways: explicitly or in a veiled way, in an evolutionary or revolutionary way, by rejecting trends pushing God and his commandments from proposed life forms and visions of the world"; "when ...";

2. For example, a) "when I experience stagnation or mediocrity in my life of faith"; b) "when everyday difficulties, troubles, and lack of time pull me away from God"; c) "when I try to grow in union with God and honor him with my life"; "when ..."

B. "What's it all about?": a possible message, an attempt to read and interpret "to some extent" the biblical key and the personal experience of faith.

1. A state of deep satisfaction, inner spiritual joy, and happiness appears

a) "when I have the feeling that I am following faith and I'm discovering God's will in it"; "when I try to live in such a way that my life is a testimony of faith and love for God and for people." Possible message: "the Lord is faithful" (2 Thessalonians 3:3, 3a); "Who but God!"; "I am the vine; you are the branches. If you remain in me and I in you, you will bear much fruit; apart from me you can do nothing." (John 15:5); "Remain in my love!" (John 15:9b); "I can do all this through him who gives me strength." (Phil 4:13); "The Lord strengthens and supports me"; "I am God's branch"; "I have a firm foundation that gives me strength in the righteous pursuit of my goal”; “...”; Possible interpretation of the message: "perhaps the spiritual, emotional experience makes us realize that "in the persons who are going on intensely cleansing their sins and rising from good to better in the service of God our Lord ... for then ... it is proper to the good to give courage and strength, consolations, tears, inspirations and quiet, easing, and putting away all obstacles, that one may go on in well doing." (Loyola, 1522-1524/2017, p. 76) or also: Possible background of this spiritually emotional experience or state is 
the action of a good spirit. The reason for such recognition and interpretation of its supernatural source is Jesus's rule of the discernment of spirits-“'Thus, by their fruit you will recognize them" (Matthew 7:20)_and the rules for the discernment of spirits, "Second Rule", speaks of how the spirit of good and evil works in those who act in the service of God.

b) "when I feel God's presence in my life and want to live in it"; Possible message_-Abba, Father!" (Rom 8:15); "You, God, are my God, earnestly I seek you; I thirst for you, my whole being longs for you, in a dry and parched land where there is no water." (Psalm 63:2); "I sing in the shadow of your wings. I cling to you; your right hand upholds me." (Psalm 63:8-9); "God loves me, I am not alone”; “...”; Possible interpretation of the message_-perhaps this kind of joy that comes from experiencing God's presence and the will to live in it, which I would call joy of consolation, may be a form of spiritual "invitation" so addressed to us by a good spirit. A possible background of this spiritually emotional experience or state is the action of a good spirit. The reason for such recognition and interpretation of its supernatural source is Jesus's rule of the discernment of spirits—-"Thus, by their fruit you will recognize them" (Matthew 7:20) — the rules for discernment of spirits, Part I, "Second Rule," and Part II, "Third Rule," which states that "with cause, as well the good Angel as the bad can console the soul, for contrary ends: the good Angel for the profit of the soul, that it may grow and rise from good to better" (Loyola, 1522-1524/2017, p. 79).

c) “when I “modernize” God's commandments and my life of faith in the spirit of ideology and cultural trends, in a variety of ways: overtly or covertly, in an evolutionary or revolutionary way, I reject those trends that oust God and His commandment from the proposed forms of life and visions of the world"; Possible message_- "you must not eat from the tree of the knowledge of good and evil, for when you eat from it you will certainly die" (Gen 2:4b-5); "I have the right to do anything" (I Cor 6:12a); "be true to yourself"; "enough with all the superstitions"; "carpe diem"; "your body belongs to you"; "enjoy life"; “..."; Possible interpretation of the message_-perhaps we are dealing here with some caricature of a genuine life of faith, expressed in actions and messages inscribed in the logic of the actions of the evil spirit, and thus with the experience that bears the hallmarks of temptation 
to be a god for ourselves. A possible background of this spiritually emotional experience or state is the action of an evil spirit. The reason for recognizing and interpreting its supernatural source this way is Jesus's rule of the discernment of spirits - "Thus, by their fruit you will recognize them" (Matthew 7:20)_and St. Paul's rule of immutability of the Gospel, unquestionably proclaimed in the Letter to the Galatians: "I am astonished that you are so quickly deserting the one who called you to live in the grace of Christ and are turning to a different gospel — which is really no gospel at all. Evidently some people are throwing you into confusion and are trying to pervert the gospel of Christ. But even if we or an angel from heaven should preach a gospel other than the one we preached to you, let them be under God's curse!" (Gal 1:6-8)

Other reasons are the rules for the discernment of spirits, Part II, “Third Rule” and Part I, "First Rule.” According to the third rule, "with cause, as well the good Angel as the bad can console the soul, for contrary ends: the good Angel for the profit of the soul, that it may grow and rise from good to better, and the evil Angel, for the contrary, and later on to draw it to his damnable intention and wickedness." (Loyola, 1522-1524/2017, p. 79)

Here, ultimately, it leads to ousting God and his commandments from my life plan and my world. Also, by analogy, the "First Rule" is another reason, illustrating the fact that "in the persons who go from mortal sin to mortal sin, the enemy is commonly used to propose to them apparent pleasures, making them imagine sensual delights and pleasures in order to hold them more and make them grow in their vices and sins" (Loyola, 1522-1524 /2017, p. 79).

2. The state of spiritual sadness, dejection, worry, and eventual despair appears

a) "when I experience stagnation or mediocrity in a life of faith"; a1.1) Possible message_- "What is this I hear about you? Give an account of your management" (Luke 16:2); "I'm spiritually lazy”; "I'm lukewarm”; “...”; Possible interpretation of the message — perhaps the one that Ignatius mentions as the first reason for distress in his "Ninth Rule." He notices in it that we may find ourselves desolate (here in the form of spiritual sadness) "because of our being tepid, lazy, or negligent in our spiritual exercises; and so through our faults, spiritual consolation withdraws from us" (Loyola, 1522-1524/2017, 
p. 76). At the same time, perhaps it is also the reason he speaks of in the "First Rule," when he draws attention to the way the good spirit works in the lives of people in a state of spiritual death, to which the situation of spiritual stagnation and mediocrity often leads. It consists in the fact that "in these persons the good spirit uses the opposite method, pricking them and biting their consciences through the process of reason" (Loyola, 1522-1524/2017, p. 75). A possible background of this spiritually emotional experience or state is the action of a good spirit. The reasons for such recognition and interpretation of its supernatural background might be the Rules for the discernment of spirits, Part I, both the "First Rule" and the "Ninth Rule"; a1.2) Possible message_- "I am the vine; you are the branches. If you remain in me and I in you, you will bear much fruit; apart from me you can do nothing." (John 15:5); "Now remain in my love!" (John 15:9b); "my Father is the gardener. He cuts off every branch in me that bears no fruit" (John 15:1b-2a); "I neglect my life of faith"; "God cares for me"; “..."; Possible interpretation of the message-perhaps the state of spiritual sadness we experience is given to us by God in order to encourage us to revive our life with him, and it so makes us realize that he cares about us and looks after us. For this purpose, by the spiritual sadness which the good spirit awakens in us, he stands at the door of our lives and "knocks" (cf. Rev 3:20), wanting us to hear his voice and open ourselves to him in this experience of spiritual desolation. Thus, let us accept his invitation, extended to us in such a state of sadness, to live with him in friendship and fellowship through a return to original zeal and conversion (cf. Rev 3:16-20); A possible background of this spiritually emotional experience or state is the action of a good spirit. The reasons for such recognition and interpretation of its supernatural background are the Rules for discernment of spirits, Part I, "First Rule," St. John's Gospel-Jesus's teaching on abiding in him and in his love (John 15:1-11) — as well the Apocalypse of John — the teaching about being spiritually "lukewarm" and the principles of exiting this kind of "lukewarmness" by restoring the original zeal and conversion-contained in the Letter to the Church in Laodicea (Rev 3:14-22); a2) Possible message- "there is no God" (Ps 53:1); "I have labored in vain; I have spent my strength for nothing at all" (Is 49:4); "You deceived me, Lord, and I was deceived; you overpowered me and prevailed. I am 
ridiculed all day long; everyone mocks me" (Jer 20:7); "What good is faith for me?"; "I don't feel the need to change anything"; "This faith is killing me"; "Isn't it better to end it all?"; "One big delusion!”; “...”; Possible interpretation of the message_perhaps it contains half-truths, discouraging reasoning, hopeless perspectives, camouflaged self-justifications, persistence in stagnation, questioning of faith, a rejection of God, that is, spiritually "toxic" messages because they distort, debilitate, or depreciate authentic experience of faith. Possible background of this spiritually emotional experience or state is the action of an evil spirit. The reason for such recognition and interpretation of its supernatural source is Jesus's rule of the discernment of spirits_- "Thus, by their fruit you will recognize them" (Matthew 7:20) — and also the rules for the discernment of spirits, Part II, the "Fifth Rule," in which Ignatius teaches us that "we ought to note well the course of the thoughts, and if the beginning, middle, and end is all good, inclined to all good, it is a sign of the good Angel; but if in the course of the thoughts which he brings it ends in something bad, of a distracting tendency, or less good than what the soul had previously proposed to do, or if it weakens it or disquiets or disturbs the soul, taking away its peace, tranquility, and quiet, which it had before, it is a clear sign that it proceeds from the evil spirit, enemy of our profit and eternal salvation" (Loyola, 1522-1524/2017, p. 79).

b) "when the hardships of everyday life, trouble, or lack of time pull me away me from God." Maybe: b1) The possible message "You, God, are my God, earnestly I seek you; I thirst for you, my whole being longs for you, in a dry and parched land where there is no water" (Ps 63:2); "Come to me, all you who are weary and burdened, and I will give you rest" (Mt 11:28); "If you remain in me and I in you, you will bear much fruit; apart from me you can do nothing" (John 15:5); "Unless the Lord builds the house, the builders labor in vain" (Ps 127:1); "You fool! This very night your life will be demanded from you" (Lk 12:20); "I do not want to live like this!"; "I miss you"; "Can't it be any other way?"; “...”; Possible interpretation of the message-perhaps the state of spiritual sadness experienced in such a way seems to bear signs of grief or longing (sounding with a note of longing), invites us in many ways to remain with God who is somehow "lost" in the whirlwind of everyday life, as if this emotional state oriented 
towards him "wanted to let us know" that "God cares for you, so through the longing and sadness that he arouses in you, he wants you not to depart from him, but to make an effort to develop the ability to experience the hardships of living with him." Possible background of this spiritually emotional experience or state is the action of a good spirit. The reason for such recognition and interpretation of its supernatural source is Jesus's rule of the discernment of spirits- "Thus, by their fruit you will recognize them" (Matthew 7:20) — the rules for the discernment of spirits, especially both Part I, the "First Rule" and Part II, the "Fifth Rule"; b2) Possible message"it's impractical!"; "Well, you can't have everything!"; "So where is God's concern for me now?”; “...”; Possible interpretation for the message_-perhaps seems to be suggested by the tinge of disappointment and doubt that resonates in this kind of messages of sadness, which I would call a sadness of disappointment and doubt. These two feelings, more or less subtly articulated, permeate me and discourage me from living with God. A possible background of this spiritually emotional experience or state is the action of an evil spirit. The reason for such recognition and interpretation of its supernatural source is Jesus's rule of the discernment of spirits_- "Thus, by their fruit you will recognize them" (Matthew 7:20) —and the rules for the discernment of spirits, especially Part II, the "Fifth Rule."

c1) "when I try to grow in union with God and make my life a testimony to him.” Maybe: $\mathrm{cl}$ ) Possible message_- "My God, my God, why have you forsaken me?" (Mt 27:46; Mk 15:34); "Why is light given to those in misery, and life to the bitter of soul”(Job 3:20); "why?”; "Jesus, I trust you”; “...” Possible interpretation of the message-perhaps this kind of sadness is a state of spiritual distress. If we were to accept such a diagnosis, then analyzing it in the context of the rules that Ignatius recommends applying when experiencing distress, we would have to ask ourselves about the reasons for which we find ourselves in such a state. Are we in distress because "[God wants us] to try and see how much we are and how much we let ourselves out in his service and praise without such great rewards as consolation and great graces" (Loyola, 1522-1524/2017, p. 77)? Or because "[God wants to give us] true acquaintance and knowledge, so that we may interiorly feel that it is not ours to get or keep great devotion, intense love, tears, or any 
other spiritual consolation, but that all is the gift and grace of God our Lord, and that we may not build a nest in a thing not ours, raising our intellect into some pride or vainglory, attributing to us devotion or the other things of the spiritual consolation" (Loyola, 1522-1524/2017, p. 77)? The possible background of this spiritually emotional experience or state is the action of a good spirit. The reasons for this recognition and interpretation of the supernatural source is Jesus's teaching about the removal of branches by the Father, "so that it will be even more fruitful" (Jn 15:2) and the rules for the discernment of spirits, Part I, the "Ninth Rule," about three principal reasons why we find ourselves desolate, here about the second and third reasons.

c2) Possible message- "Are you still maintaining your integrity? Curse God and die!" (Job 2:9); "How will you be able to endure the kind of life you have to live for 70 years?"; A possible interpretation of the message may be found in the "Second Rule" indicated in Part I of the rules for the discernment of spirits "In the persons who are going on intensely cleansing their sins and rising from good to better in the service of God our Lord ... for then it is the way of the evil spirit to bite, sadden and put obstacles, disquieting with false reasons, that one may not go on" (Loyola, 1522-1524/2017, p. 76). "A possible background of this spiritually emotional experience or state is the action of an evil spirit. The reason for such a recognition and interpretation of its supernatural source is Jesus's rule of the discernment of spirits — 'Thus, by their fruit you will recognize them' (Matthew 7:20)_and the rules for the discernment of spirits, Part I, the 'Second Rule."'

C. "What next?": an adequate response to the source/background of the emotional state. In each of the analyzed cases, if the spiritual and emotional states and the accompanying thoughts actually have a supernatural basis in the above sense, the first and basic step is to become aware of the state of one's personal life of faith, and to pay close attention to what the given state and its verbal articulation in the form of thoughts incline us to do, observing what moods they evoke in us, what understanding they inspire in us, and finally, how it all affects us, by acting in accordance with the "Fifth Rule" from the rules for the discernment of spirits. According to this rule, "we ought to note well the course of the thoughts, and if the beginning, middle, and end is all good, inclined to all good, it is a sign of the 
good Angel; but if in the course of the thoughts which he brings it ends in something bad, of a distracting tendency, or less good than what the soul had previously proposed to do, or if it weakens it or disquiets or disturbs the soul, taking away its peace, tranquility, and quiet, which it had before, it is a clear sign that it proceeds from the evil spirit, enemy of our profit and eternal salvation" (Loyola, 15221524/2017, p. 79).

1 . When it comes to the first group of typologically outlined experiences and spiritual emotional states, characterized by the influence of supernatural sources, i.e., good spirits, God and his angels, which either through the states of spiritual joy/consolation, or the states of spiritual sadness/distress, ultimately lead to the growth of faith in us, revive it and strengthen it by awakening the will to stay in touch with Jesus, by kindling love for God and people, or by purifying this faith and love-in relation to spiritual and emotional experiences and states understood in this way-accepting the "message-invitation" to the development of our humanness to reach its fullness which finds its final fulfillment in God himself, and cooperating with their spiritual sources, according to the situation in the personal life of faith in which we currently find ourselves, is the basic criterion for searching for adequate responses to the kind of actions of the good spirit in us. Answers which, depending on the recognition of the state of our life of faith, can be expressed in different forms, such as returning to God through multiple "conversions of the heart," committing to a more mature sacramental life (reconciliation, the Eucharist, etc.), i.e., living with God present in our lives, as pursuing a deeper life in prayer, and as acquiring the ability to seek and find God in everything.

2. However, taking into account the second group of typologically outlined supernatural experiences and spiritual states that, through both states of spiritual joy/consolation and spiritual sadness/distress, ultimately, one way or another, drive us away from growing in friendship with God and with people, and are identified by Ignatius in his rules as actions originating from an evil spirit, "the enemy of our profit and eternal salvation"; with regard to this kind of spiritual emotional experiences and states, Ignatius proposes several criteria for providing an adequate response to them (Loyola, 1522-1524/2017, p. 79). One of them is rejecting such experiences and states each time, in the sense of "following" them, because the goal of such agitations that "are caused in the soul" (Loyola, 1522-1524/2017, p. 76) is always to 
inflict some spiritual harm on us. ${ }^{6}$ Another, equally important response is our counteracting them accordingly, when "the person who is exercising himself in spiritual things opposes a bold front against the temptations of the enemy, doing diametrically the opposite" (Loyola, 1522-1524/2017, p. 77-78). Yet another response is not keeping secret, but sharing this kind of experience with a person experienced in the operation of the evil spirit, who is familiar with "his usual deceits" and can recognize them in the experiences and spiritual states experienced by us, under his influence (Loyola, 1522-1524/2017, p. 79). Finally, the last of these is the criterion of recognizing one's own weaknesses, thanks to careful analysis of the strategy of the evil spirit in relation to us, in order to strengthen ourselves spiritually morally and/or religiously. Ignatius notes that the evil spirit acts similarly to a commander of troops who, wishing to conquer a fortress, searches for its weakest, least defended place. "In like manner the enemy of human nature, roaming about, looks in turn at all our virtues, theological, cardinal, and moral; and where he finds us weakest and most in need for our eternal salvation, there he attacks us and aims at taking us" (Loyola, 1522-1524/2017, p. 77).

D. A specific lesson to be learned-Perhaps we are unavoidably in the "sphere of interest" of both the good and evil spirits. Nevertheless, this interest, both in the first and in the second case, has a fundamentally different purpose. While Psalm 16 accurately captures the deepest sense of the first one in the words,: "You make known to me the path of life; you will fill me with joy in your presence, with eternal pleasures at your right hand" (Ps 16:11), the sense of the latter one is equally aptly expressed by the laconic characterization of the evil spirit contained in the rules for the discernment of spirits, wherein Ignatius calls him "the enemy of our profit and eternal salvation” (Loyola, 1522-1524/2017, p. 79). Moreover, this kind of interest in us finds its real, existentially spiritual expression in their "battles" for us, which occur not somewhere "outside of us," but in our personal lives, and in these battles we are not neutral observers, but we must always pick a side.

E. A general lesson to be learned. Perhaps the fact that in all the typologically analyzed cases of experiences and emotional states, with

6 We find this kind of criterion both in justifying the purpose of the rules, in the laconic statement that they serve- " for perceiving and knowing in some manner the different movements which are caused in the soul the good, to receive them, and the bad to reject them," and in the rules themselves. 
both natural and supernatural backgrounds, we always experience them integrally as bodily-spiritual beings, although in our analyses of these experiences, we usually focus only on specific dimensions of our lives which the case in question relates to in a particularly significant way. What seems to be an obvious and banal statement at its core turns out not to be one in the least when we ask what it means that, firstly, we participate in every experience integrally, and, secondly, that we participate in it precisely as bodily and spiritual beings? Such a question necessarily touches on the issue of possible references and relationships between experiences and emotional states aroused by one or another source, proper to the different dimensions of one and the same humanity which has been discussed in this study so far. In the same vein, it puts the center of attention on the integrity of our existence as human beings and its dynamic character, important in the context of our humanity in the world "here and now" and, at the same time, in the horizon of Transcendence, which reveals itself to us through religious experience. On the other hand, it touches on the issue of our human carnality, which constitutes our way of being human as bodily-spiritual beings in the world given to us, namely, its essence, importance, and inalienability, on the premise that everything we do in any area of our existence-physical, mental, or spiritual —is always somehow mediated through this corporeality. It is through our corporeality that we express who we are, what our values are, how we understand the meaning of life, who we want to be for ourselves and for other people, and who we want to be for God. In our bodies, we also realize all these understandings and our existentially important attitudes inspired by them, from love and acceptance of ourselves and the Other (man and God), to hatred and rejection of ourselves and each and every Other.

I intend to devote the third part of this essay series to these questions, asking about their biblical and philosophical interpretations and the possible implications and inspirations proceeding from them, which still remain valid today. As for the study proposed in this part on reading feelings, of course, it does not exhaust the complexity of emotionality and is not intended to do so; nor is it meant to be the only, first, or best one. Instead, this essay is guided by the intention of becoming a contribution to learning to understand ourselves in this important area of our humanity, which will also become the subject of the third part of the series. 


\section{REFERENCES}

Dybel, P. [2012]. Oblicza hermeneutyki. Krakow: TAiWPN Uniwersitas.

Fedeli, M. (2003). Temperamenty, charaktery, osobowośc. Profil medyczny i psychologiczny [Temperaments, characters, personality: A medical and psychological profile]. Krakow: WAM Publishing House.

Loyola, I. (2001). A pilgrim's fourney: The autobiography of Ignatius of Loyola (Joseph N. Tylenda, Trans.). San Francisco: Ignatius Press.

Loyola, I. (2017). The spiritual exercises of St. Ignatius of Loyola (Father Elder Mullan, Trans.). San Francisco: Ignatius Press.

Plato. (2008). The Republic (B. Jowett, Trans.). https://www.gutenberg.org/ files/1497/1497-h/1497-h.htm (Original work published ca. 375 BCE)

Scheler, M. (1967). Materialne apriori w etyce [The material a priori in ethics]. Znak 12/162.

Steinbeck, J. (2001). The log from the Sea of Cortez. London: Penguin.

The Bible, New International Version. (2011). Bible Gateway. www.biblegateway.com/versions/New-International-Version-NIV-Bible

Tomasz Homa-Jesuit, philosopher, and professor at the Jesuit University Ignatianum in Krakow. In his research he deals with issues concerning social and political philosophy, existentialism, ethics, and culture. He has written monographs on social and political philosophy-W $-W$ rodze do podmiotowości spoteczenstwa [On the Way to the Subjectivity of Society], Obywatelskość [Citizenship], and Wspólnotowość [Communality]—and co-authored Problemy wspótczesności a chrześcijanie [Problems of the Present Day and Christians] and Zagadnienia etyczne i spoteczne do dyskusji dla mtodziezy $i$ wychowawców [Ethical and Social Issues for Discussion for Young People and Educators]. 